\title{
PPG Students' Learning Competency Analysis From Self Regulated Learning Factors
}

\section{Mawardi1 ${ }^{*}$, Henny Dewi Koeswanti2}

1,2 Fakultas Keguruan dan Ilmu Pendidikan, Universitas Kristen Satya Wacana, Salatiga, Indonesia

\section{ART ICLE INFO}

\section{Article history:}

Received August 10, 2021

Revised August 11, 2021

Accepted October 07, 2021

Available online November 25, 2021

\section{Kata Kunci:}

Self Regulated Learning,

Kompetensi Mahasiswa, PPG

Keywords:

Self Regulated Learning, Student' Competencies, PPG

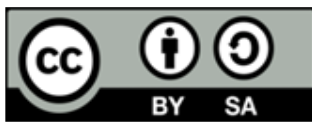

This is an open access article under the CC BY-SA license.

Copyright $\left({ }_{0} 2021\right.$ by Author. Published by Universitas Pendidikan Ganesha.

\begin{abstract}
A B S T R A K
Pengalaman pelaksanaan program Pendidikan Profesi Guru (PPG) Guru Kelas SD selama ini menunjukkan bahwa tingkat kelulusan peserta PPG baru mencapai rerata $70 \%$ untuk keseluruhan angkatan. Kondisi ini tentu menjadi bahan refleksi bagi pengelola untuk meningkatkan kinerjanya agar mecapai hasil yang lebih optimal di masa mendatang. Tujuan penelitian ini yaitu untuk menganalisis kompetensi mahasiswa PPG, pencapaian kompetensi mahasiswa, dan menganalisis perbedaan kompetensi mahasiswa berdasarkan SRL tinggi dan rendah. Jenis penelitian ini yaitu Penelitian deskriptif kuantitatif, dengan metode korelasional komparatif. Teknik dan instrumen yang digunakan adalah teknik analisis dokumen kompetensi mahasiswa dan The SRL Measurement Instrument. Sampel dalam penelitian ini sejumlah 34 mahasiswa PPG. Tehnik analisis data menggunakan teknik statistik deskriptif, analisis regresi linier dan uji t. Hasil penelitian menemukan bahwa rerata skor tingkat SRL mahasiswa mencapai 88,76; rerata skor kompetensi mahasiswa PPG mencapai 90,44; kontribusi SRL terhadap kompetensi mahasiswa sebesar 15,8\%; serta mahasiswa yang memiliki SRL tinggi secara signifikan lebih tinggi pula dalam pencapaian kompetensi belajarnya. Dapat disimpulkan bahwa keseluruhan tingkat $S R L$ mahasiswa dapat dikatakan sangat tinggi.
\end{abstract}

\section{A B S T R A C T}

The experience of implementing the Teacher Professional Education (PPG) for Elementary School Teacher Program so far shows that the graduation rate for PPG participants has only reached an average of $70 \%$ for the entire class. This condition is undoubtedly a reflection material for managers to improve their performance to achieve more optimal results in the future. This study aimed to analyze PPG student competence, student competence, and differences in student competence based on SRL and low. This type of research is descriptive quantitative research with the comparative correlational method. Techniques and instruments used are student competency document analysis techniques and SRL Measurement Instruments. The sample in this study was 34 PPG students. Data analysis techniques used descriptive statistical techniques, linear regression analysis and t-test. The results of the study found that the average student SRL level score reached 88.76; the average competency score of PPG students reached 90.44 ; the contribution of SRL to student competence is $15.8 \%$; and students who have SRL significantly in their learning competence. It can be said that all student SRL levels can be said to be very high.

\section{INTRODUCTION}

The experience of implementing the Elementary School Teacher Professional Education (PPG) program at the Satya Wacana Christian University (SWCU) so far shows that the PPG participant graduation rate has only reached an average of $70 \%$ for the entire class. The achievement of this graduation average is already better than the average passing rate of the PPG program at the beginning of this program. Research on the evaluation of the PPG program reported that almost 50\% of PPG SM3T participants did not pass the national written exam (Prasojo et al., 2017). This condition is undoubtedly a reflection material for managers to improve their performance to achieve more optimal results in the future. Moreover, the issue of the Covid-19 pandemic has not subsided and has forced the learning delivery system to be carried out online (Adedoyin \& Soykan, 2020; Korkmaz \& Toraman, 2020; Sari et al., 2021; Syauqi et al., 2020). Various 
elements that appear related to the lack of maximum competence of the students mentioned above are the students' problem of Self Regulated Learning (SRL) (Hwang et al., 2020; Xiao \& Yang, 2019). Competence is a set of knowledge, skills, and behaviours that must be possessed, internalized, and mastered in carrying out professional duties (Kusumayani et al., 2019; Rudiyati, 2013; Yulyani et al., 2020). Competence can also be interpreted as a combination of knowledge, skills, values, and attitudes reflected in the habits of thinking and acting (Setiyowati \& Arifianto, 2020; Sitasih, 2020). Self-Regulated Learning (SRL) is a process in which students move, change, and maintain learning activities both independently and in their social environment, in informal and formal instructional contexts (Hwang et al., 2020; Xiao \& Yang, 2019). Some experts on SelfDirected Learning (SDL) provide limitations that SDL $(=S R L)$ is a student's behaviour in naturally realizing his will or desire without depending on others. In this case, the student can do his learning, can determine how to learn practical, carry out learning tasks well, and carry out learning activities independently (Brockett \& Hiemstra, 2018; Hong et al., 2021). In addition, SRL or independent learning is an active learning activity, which is driven by an intention or motive to master competency in order to overcome a problem and is built with the knowledge or competencies that have been possessed (J. H. Chen et al., 2019; Ranti et al., 2017; Vrieling et al., 2012).

Self-Direct Learning (SDL) is a learning process in which learners carry out active learning activities, which are motivated by a motive to overcome a problem, and are built with the knowledge or competencies they have, as well as monitor, regulate and control their thoughts and behaviour to achieve goals. Specific competencies (Aryani \& Hasyim, 2018; Wong et al., 2021). The elements of competence include 1) knowledge, skills and attitudes as the basis for forming competence; 2) competence is a person's capability in doing a task; 3) achieving competence as a result of applying one's capabilities in carrying out their professional duties (Y.-L. Chen \& Hsu, 2020). Thus it becomes clear that SRL is a self-directed process through which learners convert their mental abilities into academic skills. SRL is one of the determinants of student academics. Evidence suggests that students who organize their learning perform better in school than those not involved in self-regulation (Ahmed, 2017; Dent \& Koenka, 2016).

Teacher competence (as PPG students) is the ability to carry out their professional duties productively armed with the knowledge, skills and values they master (Rudiyati, 2013; Yulyani et al., 2020). So, teacher competence is essentially a concretization of the knowledge, skills and values that are mastered. SRL is self-direction by converting mental abilities into academic skills to achieve specific academic achievements, meaning that SRL is theoretically correlated with student competence (Ranti et al., 2017; Vrieling et al., 2012). Self-Regulated Learning measured using a questionnaire can predict a person's learning outcomes. Other research findings also state that SRL affects student competence (Mawardi, 2020). From these two views, it appears that SRL is related to learning competence. It means that if a student has a high SRL level, he will also get a high learning outcome score (Hwang et al., 2020; Xiao \& Yang, 2019). In this study, a review of the relevant research results was carried out. Both regression studies, experiments, and R\&D research are related to the relationship between SRL as a whole and partially with student competencies. Regression research using a meta-analysis approach to Systematic Literature Review on Selfregulated learning strategies \& academic achievement in online higher education learning environments found that aspects of Self-regulated learning (SRL) related to time management strategies, metacognition, effort management, and thinking critically correlated positively with academic outcomes (Anthonysamy et al., 2020; Broadbent \& Poon, 2015). Research on Enhancing self-regulated learning in higher education found that the concept of self-regulated learning with a learning model and the factors that contribute to applying adequate self-regulation strategies depend on individual characteristics but generally lead students to more meaningful learning, greater satisfaction in learning, and better learning outcomes (Šteh \& Šarić, 2020; Zheng \& Zhang, 2020). Previous research found that the application of online learning had a positive impact on SRL and student competence (Kusuma, 2020). Based on the problems and theoretical buildings that were compiled, this study aimed to analyze the SRL of PPG students for elementary school teachers.

\section{METHOD}

The type of research that will be applied in this research is quantitative research, with a comparative correlational method. The independent variable studied in this study is Self Regulated Learning (SRL) as the primary independent variable (X), in which there are sub-variables, including motivation (X1), goal-oriented (X2), self-controlling behaviour (X3). Moreover, armed with prior knowledge that has been mastered (X4). At the same time, the gayut variable in this study is the competence of PPG students (Y). The techniques and instruments used are student competency document archive analysis techniques. This SRL instrument consists of 30 items. The instrument has been tested for validity and reliability of the instrument with $(n)=30$ students, where it is found that the reliability coefficient level 
of Cronbach's Alpha is 0.831 , and the Corrected item-total Correlation validity coefficient moves between 0.298 to 0.660 ; these figures illustrate that the instrument is reliable and valid. The sample in this study was 34 PPG students. The data analysis technique used descriptive statistical techniques and analysis techniques to test the reliability and validity of the instrument to ensure that the SRL instrument to be used was valid and reliable. Furthermore, before the regression and t-test were carried out, the classical assumption test was carried out first, including tests for normality, linearity, homoscedasticity, multicollinearity, and autocorrelation. If the assumption test is met, then proceed with regression analysis to analyze the contribution of the $\mathrm{X}$ variable to $\mathrm{Y}$, the significance of its contribution and the $\mathrm{t}$-test.

\section{RESULT AND DISCUSSION}

\section{Result}

Results Based on data analysis, students' SRL levels were in the very high category (94\%) and the high category (6\%). Partially on the motivational aspect (X1), it is in the very high category (71\%) and the high category (29\%). In the goal-oriented aspect (X2), the distribution of student SRL levels is in the very high category (88\%) and the high category (12\%). In the aspect of controlling self-behaviour (X3), the distribution of student SRL levels is in the very high category (100\%). In the aspect of armed with prior knowledge (X4), the distribution of student SRL levels is in the very high category (79\%), high category (3\%), medium category (12\%), low category (3\%) and deficient category (3\%). In the student competency variable (Y), it was found that the overall student competency level was in the very high category $(100 \%)$, and there were no other categories. It means that the overall SRL level of students can be said to be very high. In the independent material deepening component, the distribution of the level of competence is in the very high category (100\%). In the Implementation of Learning Practices (PPL) component, the distribution of the level of competence is in the very high category (100\%). In the Comprehensive Test Result (UK) component, the distribution of competency levels is in the very high category (94\%) and the high category $(6 \%)$. It is also in line with previous research, which found that SRL-based e-learning content can improve learning outcomes (Wahyuni et al., 2020).

The description of the magnitude of the contribution of SRL to the competence of PPG students is based on the output of simple and multiple regression analysis assisted by the SPSS version 22 program. The contribution of the SRL level to the motivation aspect is in the R-Square coefficient of determination of 0.053. It means that the contribution amount is $5.3 \%$ and is in the deficient category. In the goal-oriented aspect, the coefficient of determination R-Square is 0.005 . This means the contribution amount of $0.5 \%$ is also in the deficient category. In the aspect of self-control, it is found that the coefficient of determination $\mathrm{R}$-Square is 0.092 . The contribution amount is $9.2 \%$, which is also in the deficient category. In the aspect of Armed with prior knowledge, the coefficient of determination R-Square is 0.123 . It means that the contribution amount is $12.3 \%$, also in the deficient category. It is found that the coefficient of determination $\mathrm{R}$-Square is 0.158 . This means that the contribution amount is $15.8 \%$, also in the deficient category. Based on data on the percentage contribution of SRL, either partially or jointly. It moves between $0.5 \%$ to $15.8 \%$, with an average of $8.62 \%$. It appears that all SRL contributions are in the deficient category. The role of SRL in achieving PPG student competence is minimal, only $0.5 \%$ to $15.8 \%$, with an average of $8.62 \%$, mostly $99.5 \%$ to $84.2 \%$. The average of $91.38 \%$ comes from another variable. It means that the level of student competence is not due to the role of SRL but because of other variables. If the findings of this data are seen for their significance through hypothesis testing, through a significance test based on SPSS output, it appears that in the aspect of motivation, an F value of 1.795 is obtained, and a significance probability number is 0.190 , with $=0.05$, then the significance number is $0.190>=0.05$, so it is not significant. If it is associated with Hypothesis 1 (H1), it means that $\mathrm{H} 0$ is accepted and Ha is rejected, so there is no significant positive contribution between the motivational aspect and PPG student competence.

In the SPSS output of the Goal_Oriented aspect, the F value is 0.159 , and the significance probability number is 0.693 . Because the significance number is $0.693>=0.05$, it is declared not significant. If it is associated with $\mathrm{H} 2$, it means that $\mathrm{H} 0$ is accepted and $\mathrm{Ha}$ is rejected, so that there is no significant positive contribution between the Goal-Oriented aspect and the competence of PPG students. In the Self-Control aspect, the $\mathrm{F}$ value is 3.224 , and the significance probability number is 0.082 . If we compare it with $=0.05$, then the significance number is $0.082>=0.05$, so it is declared insignificant. Thus, if it is associated with $\mathrm{H} 3$, then $\mathrm{HO}$ is accepted, and $\mathrm{Ha}$ is rejected so that there is no significant positive contribution between the aspects of Self-Control and PPG student competence. In the Bekal_Initial aspect, the F value is 4.477, and the significance probability number is 0.042 . If we compare it with $=0.05$, then the significance number is 0.042 $<=0.05$, so it is declared significant. Thus, if it is associated with $\mathrm{H} 4$, then $\mathrm{H} 0$ is rejected, and Ha is accepted. It means that there is a significant positive contribution between the Initial Provisions aspect and the competence of PPG students. 
In all aspects of SRL together, the F value is 1.360 , and the significance probability value is 0.167 , $0.807,0.690,0.289$, respectively. If we compare it with $=0.05$, then all significant figures $>=0.05$, so it is declared insignificant. Thus, testing $\mathrm{H} 5$ is that $\mathrm{H} 0$ is accepted and $\mathrm{Ha}$ is rejected. It means that there is no significant positive contribution between motivation, goal-oriented, self-controlling behaviour, and the provision of prior knowledge that has been mastered together with the competence of PPG students. The data on the significance of the regression test results and hypothesis testing that have been described above provide information that, in general, SRL does not contribute to the achievement of student competencies. There is only one aspect of SRL, armed with prior knowledge (X4), which significantly contributes to student competence $(\mathrm{Y})$, amounting to $12.3 \%$. The finding is that SRL does not contribute to student competencies. It is in line with the two experimental research findings that stated no significant effect of SRL-support condition and No-SRL-support condition on SRL online activities and learning outcomes. SRL interventions may have different effects on student achievement and student engagement in SRL activities (Jansen et al., 2019; Van Alten et al., 2020). Based on the results of data analysis, the t count is 6.803 with a significance level of 0.000 . Based on the data from this t-test, the sixth hypothesis can be tested. The sixth hypothesis (H6) which states H0: -SRL_high - SRL_low: The high SRL level of PPG students does not contribute higher to student competence; Ha: -SRL_high > -SRL_low: The high SRL level of PPG students contributed more to student competence $\mathrm{H} 0$ was rejected and accepted Ha because $0.000<=0.050$, meaning that the high SRL level of PPG students contributed higher to their competence. This finding is by the results of previous studies, which stated that there was no difference in learning outcomes to write text reports on observations shown by groups of subjects who had high SRL and groups of subjects who had low SRL (Reni \& Kuswandi, 2018). Likewise, in line with other research, the results found that the application of online learning had a positive impact on SRL and student competence during distance learning (Kusuma, 2020).

\section{Discussion}

The high achievement of this student SRL is believed to come from the design of an online learning model using the Moodle LMS (https://elearning-ppgdaljab.simpkb.id), with an activity-based problemsolving approach. This statement is in line with research findings which state that the level of student selfregulated learning in learning using Open Learner Models based on blended learning assisted by Moodle LMS is significantly higher than learning using other learning models (Mawardi et al., 2015; Tongchai, 2016). The design of problem-solving activity-based learning that can grow student SRL is also in line with previous research, which states that the flipped classroom learning model increases student self-regulated learning but has not provided a significant increase in the control class (Sinaga, 2017). The general finding that SRL does not contribute to the achievement of these competencies is also in line with three regression studies, which found that SRL correlated very low and insignificantly with academic achievement in an online context than in a traditional classroom. SRL has a meagre contribution, even inversely proportional to the achievement of student competencies. Other factors are thought to have a more impact, such as student involvement in their learning tasks (Broadbent \& Poon, 2015; Zheng \& Zhang, 2020).

On the other hand, the findings of this study which states that SRL does not contribute to the achievement of competence, are shocking because they are not in line with the theoretical building that we have compiled and are inconsistent with various relevant studies that the following other researchers have carried out. First, experimental research found that SRL-based learning designs, such as Open Learner Models (OLMs) moderated by SRL and SRL-based e-learning as experimental models had a significantly higher impact on student competence than other models (Long \& Aleven, 2017; Tongchai, 2016; Wahyuni et al., 2020). The SRL-based learning models developed, such as the SRL-based e-learning model and the peer SRL skill intervention model, have been proven to impact student learning competencies significantly. Various regression studies have found that the concept of self-regulated learning, the learning model, and the factors that contribute to the implementation of self-regulation strategies depend on individual characteristics. However, learning is generally more meaningful, significant, and higher learning outcomes. better (Shea et al., 2013; Šteh \& Šarić, 2020; Tentama \& Riskiyana, 2020). Previous research stated that there are fourteen SRL strategies used in online learning; Surprisingly, in learning activities, cognitive and metacognitive strategies that tend to be non-academic do not appear in the online learning used (Anthonysamy et al., 2020).

\section{CONCLUSION}

The average competency score of PPG students is in the very high category. The contribution of each SRL aspect to student competence in the motivational aspect is in the deficient and insignificant category. Students with a high SRL are also significantly higher in achieving their learning competencies. It can be concluded that the overall SRL level of students can be said to be very high. 


\section{REFERENCES}

Adedoyin, O. B., \& Soykan, E. (2020). Covid-19 pandemic and online learning: the challenges and opportunities. In Interactive Learning Environments. https: //doi.org/10.1080/10494820.2020.1813180.

Ahmed, W. (2017). Motivation and self-regulated learning: A multivariate multilevel analysis. International Journal of Psychology and Educational Studies, 4(3). https://doi.org/10.17220/ijpes.2017.03.001.

Anthonysamy, L., Koo, A. C., \& Hew, S. H. (2020). Self-regulated learning strategies and non-academic outcomes in higher education blended learning environments: A one decade review. Education and Information Technologies, 1. https://doi.org/10.1007/s10639-020-10134-2.

Aryani, T. D., \& Hasyim, M. (2018). Pengaruh Kecemasan Matematis, Problem Stres Matematika dan SelfRegulated Learning terhadap Hasil Belajar Matematika Siswa. Aksioma, 7(2), 243-252. https://doi.org/10.24127/ajpm.v7i2.1422.

Broadbent, J., \& Poon, W. (2015). Self-regulated learning strategies \& academic achievement in online higher education learning environments: A systematic review. The Internet and Higher Education, 27. https://doi.org/10.1016/j.iheduc.2015.04.007.

Brockett, R. G., \& Hiemstra, R. (2018). Self-direction in adult learning: Perspectives on theory, research, and practice. Routledge, 1. https://doi.org/10.4324/9780429457319.

Chen, J. H., Björkman, A., Zou, J. H., \& Engström, M. (2019). Self-regulated learning ability, metacognitive ability, and general self-efficacy in a sample of nursing students: A cross-sectional and correlational study. Nurse Education in Practice, 37. https://doi.org/10.1016/j.nepr.2019.04.014.

Chen, Y.-L., \& Hsu, C.-C. (2020). Self-regulated mobile game-based English learning in a virtual reality environmen. Computers \& Education, 154. https://doi.org/10.1016/j.compedu.2020.103910.

Dent, A. L., \& Koenka, A. C. (2016). The relation between self-regulated learning and academic achievement across childhood and adolescence: A meta-analysis. Educational Psychology Review, 28(3). https://doi.org/10.3389/fpsyg.2017.00422.

Hong, J.-C., Lee, Y.-F., \& Ye, J.-H. (2021). Procrastination predicts online self-regulated learning and online learning ineffectiveness during the coronavirus lockdown. Personality and Individual Differences, 174, 110673. https://doi.org/10.1016/j.paid.2021.110673.

Hwang, G. J., Wang, S. Y., \& Lai, C. L. (2020). Effects of a social regulation-based online learning framework on students' learning achievements and behaviors in mathematics. Computers and Education, 160, 104031. https://doi.org/10.1016/j.compedu.2020.104031.

Jansen, R. S., Leeuwen, V., Janssen, \& Kester. (2019). Self-regulated learning partially mediates the effect of self-regulated learning interventions on achievement in higher education: A meta-analysis. Educational Research Review, 28. https://doi.org/10.1016/j.edurev.2019.100292.

Korkmaz, G., \& Toraman, C.. (2020). Are We Ready for the Post-COVID-19 Educational Practice? An Investigation into What Educators Think as to Online Learning. International Journal of Technology in Education and Science, 4(4), 293-309. https://doi.org/10.46328/ijtes.v4i4.110.

Kusuma, D. A. (2020). Dampak penerapan pembelajaran daring terhadap kemandirian belajar (selfregulated learning) mahasiswa pada mata kuliah geometri selama pembelajaran jarak jauh di masa pandemi covid-19. Teorema: Teori Dan Riset Matematika, 5(2). https://doi.org/10.25157/teorema.v5i2.3504.

Kusumayani, N. K. M., Wibawa, I. M. C., \& Yudiana, K. (2019). Pengaruh Model Pembelajaran Kooperatif Talking Stick Bermuatan Tri Hita Karana Terhadap Kompetensi Pengetahuan Ipa Siswa Iv Sd. Jurnal Pendidikan Multikultural Indonesia, 2(2), 55. https: //doi.org/10.23887/jpmu.v2i2.20805.

Long, Y., \& Aleven, V. (2017). Enhancing learning outcomes through self-regulated learning support with an open learner model. User Modeling and User-Adapted Interaction, 27(1). https://doi.org/10.1007\%2Fs11257-016-9186-6.

Mawardi. (2020). Keefektifan Flexible Learning dalam Menumbuhkan Self-Regulated Learning dan Hasil Belajar Mahasiswa PGSD. Scholaria: Jurnal Pendidikan Dan Kebudayaan, 10(3). https://doi.org/10.24246/j.js.2020.v10.i3.p251-262.

Mawardi, Mudjiman, H., Anitah, S., \& Asrowi. (2015). The Model of Instructional Design Based on SelfRegulated Learning using Modular Object Oriented Dynamic Learning Environment (MOODLE). Journal of Education and Practice, 5(22).

Prasojo, L. D., Wibowo, U. B., \& Hastutiningsih, A. D. (2017). Manajemen Kurikulum Program Profesi Guru Untuk Daerah Terdepan, Terluar, Dan Tertinggal Di Universitas Negeri Yogyakarta. Jurnal Pendidikan Dan Kebudayaan, 2(1). https://doi.org/10.24832/jpnk.v2i1.538.

Ranti, M. G., Budiarti, I., \& Trisna, B. N. (2017). Pengaruh Kemandirian Belajar (Self Regulated Learning) Terhadap Hasil Belajar Mahasiswa Pada Mata Kuliah Struktur Aljabar. Math Didactic, 3(1), 75-83. https://doi.org/10.33654/math.v3i1.57. 
Reni, Y. M., \& Kuswandi, D. (2018). Pengaruh Strategi Pembelajaran dan Self Regulated Learning Terhadap Hasil Belajar. JINOTEP (Jurnal Inovasi Dan Teknologi Pembelajaran), 10(1). https://doi.org/10.17977/um031v4i12017p047.

Rudiyati, S. (2013). Peningkatan Kompetensi Guru Sekolah Inklusif Dalam Penanganan Anak Berkebutuhan Pendidikan Khusus Melalui Pembelajaran Kolaboratif. Cakrawala Pendidikan, 1(2). https://doi.org/10.21831/cp.v0i2.1488.

Sari, R. P., Tusyantari, N. B., \& Suswandari, M. (2021). Dampak Pembelajaran Daring Bagi Siswa Sekolah Dasar Selama Covid-19. Prima Magistra: Jurnal Ilmiah Kependidikan, 2(1), 9-15. https://doi.org/10.37478/jpm.v2i1.732.

Setiyowati, E. P., \& Arifianto, Y. A. (2020). Hubungan Kompetensi Pedagogik Guru dan Prestasi Belajar Siswa pada Mata Pelajaran Pendidikan Agama Kristen. SIKIP: Jurnal Pendidikan Agama Kristen, 1(2), 7895. https://doi.org/10.52220/SIKIP.V1I2.57.

Shea, P., Hayes, S., Uzuner Smith, S., Vickers, J., Bidjerano, T., Gozza-Cohen, M., Jian, S. B., Pickett, A. M., Wilde, J., \& Tseng, C. H. (2013). Online learner self-regulation: Learning presence viewed through quantitative content- and social network analysis. International Review of Research in Open and Distance Learning, 14(3), 427-461. https://doi.org/10.19173/irrodl.v14i3.1466.

Sinaga. (2017). Penerapan Flipped Classroom Pada Mata Kuliah Kimia Dasar Untuk Meningkatkan SelfRegulated Learning Belajar Mahasiswa. Jurnal Inovasi Pendidikan Kimia, 11(2).

Sitasih, D. K. (2020). Supervisi Akademik untuk Meningkatka Kompetensi Guru Dalam Proses Pembelajaran di SD. Jurnal Ilmiah Sekolah Dasar, 4(1). https://doi.org/10.23887/jisd.v4i2.25461.

Šteh, \& Šarić. (2020). Enhancing self-regulated learning in higher education. Journal of Elementary Education, 1. https://doi.org/10.18690/rei.13.Special.129-150.2020.

Syauqi, K., Munadi, S., \& Triyono, M. B. (2020). Students' perceptions toward vocational education on online learning during the COVID-19 pandemic. International Journal of Evaluation and Research in Education (IJERE), 9(4), 881. https://doi.org/10.11591/ijere.v9i4.20766.

Tentama, F., \& Riskiyana, E. R. (2020). The role of social support and self-regulation on work readiness among students in vocational high school. International Journal of Evaluation and Research in Education, 9(4), 826-832. https://doi.org/10.11591/ijere.v9i4.20578.

Tongchai, N. (2016). Impact of self-regulation and open learner model on learning achievement in blended learning environment. International Journal of Information and Education Technology, 6(5). https://doi.org/10.7763/IJIET.2016.V6.711.

Van Alten, D. C. D., Phielix, C., Janssen, J., \& Kester, L. (2020). Self-regulated learning support in flipped learning videos enhances learning outcomes. Computers and Education, 158(August), 104000. https://doi.org/10.1016/j.compedu.2020.104000.

Vrieling, E. M., Bastiaens, T. J., \& Stijnen, S. (2012). Effects of increased self-regulated learning opportunities on student teachers' metacognitive and motivational development. International Journal of Educational Research, 53. https://doi.org/10.1016/j.ijer.2012.03.014.

Wahyuni, A. S., Warpala, I. W. S., \& Agustini, K. (2020). Pengembangan Konten E-Learning Berbasis Self Regulated Learning untuk Meningkatkan Hasil Belajar Airline Reservation. Jurnal Teknologi. https://doi.org/10.23887/jtpi.v10i1.3394.

Wong, J., Baars, M., He, M., de Koning, B. B., \& Paas, F. (2021). Facilitating goal setting and planning to enhance online self-regulation of learning. Computers in Human Behavior, 124(June). https://doi.org/10.1016/j.chb.2021.106913.

Xiao, Y., \& Yang, M. (2019). Formative assessment and self-regulated learning: How formative assessment supports students' self-regulation in English language learning. System, 81. https://doi.org/10.1016/j.system.2019.01.004.

Yulyani, Y., Kazumaretha, T., Arisanti, Y., Fitria, Y., \& Desyandri, D. (2020). Implementasi Kompetensi Pedagogik Guru Dalam Pembelajaran Tematik Di Sekolah Dasar. School Education Journal Pgsd Fip Unimed, 10(2), 184. https://doi.org/10.24114/sejpgsd.v10i2.18545.

Zheng, B., \& Zhang, Y. (2020). Self-regulated learning: the effect on medical student learning outcomes in a flipped classroom environment. BMC Medical Education, 20(1). 